\title{
Research
}

\section{Cross-Scale Value Trade-Offs in Managing Social-Ecological Systems: The Politics of Scale in Ruaha National Park, Tanzania}

\author{
$\underline{\text { Asim Zia }}^{1}$, Paul Hirsch $^{2}, \underline{\text { Alexander Songorwa }}^{3}$, David R. Mutekanga $^{4}$, Sheila O'Connor $^{5}{ }^{5}$ Thomas McShane $^{5}$, \\ $\underline{\text { Peter Brosius }}^{6}$, and Bryan Norton ${ }^{7}$
}

\begin{abstract}
Management of social-ecological systems takes place amidst complex governance processes and cross-scale institutional arrangements that are mediated through politics of scale. Each management scenario generates distinct cross-scale trade-offs in the distribution of pluralistic values. This study explores the hypothesis that conservation-oriented management scenarios generate higher value for international and national scale social organizations, whereas mixed or more balanced management scenarios generate higher value for local scale social organizations. This hypothesis is explored in the management context of Ruaha National Park (RNP), Tanzania, especially the 2006 expansion of RNP that led to the eviction of many pastoralists and farmers. Five management scenarios for RNP, i.e., national park, game reserve, game control area, multiple use area, and open area, are evaluated in a multicriteria decision analytical framework on six valuation criteria: economic welfare; good governance; socio-cultural values; social equity; ecosystem services; and biodiversity protection; and at three spatial scales: local, national, and international. Based upon this evaluation, we discuss the politics of scale that ensue from the implementation of management alternatives with different mixes of conservation and development goals in social-ecological systems.
\end{abstract}

Key Words: biodiversity conservation; complexity; ecological valuation; economic development; politics of scale; socialecological systems; trade-off analysis

\section{INTRODUCTION}

The tension between conservation and development objectives across the globe is a function of many complex issues (Hirsch et al. 2011, McShane et al. 2011), one of which concerns how to trade off pluralistic values associated with anthropogenic environmental change occurring at multiple scales of space and time. Recently, a considerable amount of research and scholarship has been devoted to understanding the cross-scale trade-offs that ensue from the management of social-ecological systems at multiple levels of social organization (e.g., Berkes 2002, 2006, Adger et al. 2005, Brown and Purcell 2005, Lebel et al. 2005, Rodriguez et al. 2006, Silver 2008). This study is an attempt to analyze crossscale trade-offs in the management of social-ecological systems from the perspective of the politics of scale, which involves an explicit focus on the ways in which powerful actors at larger scales of social and spatial organization influence the policies and management of social-ecological systems at relatively smaller scales. Although literature on the politics of scale in political economy and political geography (Smith 1992, 1993, 1995, Jonas 1994, Agnew 1997, Delaney and Leitner 1997, Swyngedouw 1997a,b,c, 2000, Howitt 1998, Marston 2000, Brenner 2001, Escobar 2001), and more recently political ecology (Brown and Purcell 2005, Cash et al. 2006), has focused on assessing the strategies pursued by individuals or groups across different spatial levels of social organization to achieve a particular agenda, this paper incorporates the basic insights put forward by theorists of the politics of scale with the goal of quantifying differences in the valuation of management alternatives across multiple spatial scales of social organization.

Our central theoretical argument is that management alternatives, each of which is associated with different mixes of development and conservation goals, lead to the emergence of asymmetric distributions of value for different social organizational groups across spatial scales. We hypothesize that conservation-oriented or development-oriented extreme management scenarios generate higher value for international and national scale social organizations, whereas mixed or balanced management scenarios generate higher value for local scale social organizations. Management of socialecological systems is thus a dynamic interplay of politics of scale, creating and recreating winners and losers at multiple spatial scales with the implementation of different mixes of conservation and development policies. We explore this hypothesis in the empirical context of management options at Ruaha National Park (RNP).

Ruaha National Park (Fig. 1) covers approximately 10,300 $\mathrm{km}^{2}$ and is the second largest of all the Tanzanian national parks. RNP takes its name from the Great Ruaha River that flows along its eastern border. The RNP is part of a series of

\footnotetext{
${ }^{1}$ Department of Community Development and Applied Economics, University of Vermont, ${ }^{2}$ Department of Environmental Studies SUNY College of Environmental Science and Forestry, Syracuse NY, ${ }^{3}$ Department of Wildlife Management, Sokoine University of Agriculture, Morogoro, Tanzania, ${ }^{4}$ Wildlife Conservation Society, Ruaha National Park, Tanzania, ${ }^{5}$ Global Institute of Sustainability, Arizona State University, Tempe AZ, ${ }^{6}$ Center for Integrative Conservation Research, University of Georgia, Athens GA, ${ }^{7}$ School of Public Policy, Georgia Institute of Technology, Atlanta GA
} 
conjoined wildlife areas, covering $50,000 \mathrm{~km}^{2}$ and stretching as far as Katavi in the west. A recent controversy arose from the expansion of the RNP when the adjacent Usangu Game Reserve was upgraded to a National Park status, and as a result, residents of seven villages were relocated to other areas.

Fig. 1. Location of Ruaha National Park in Tanzania. Source: http://www.tanzaniaparks.com/tanzania_map.html.

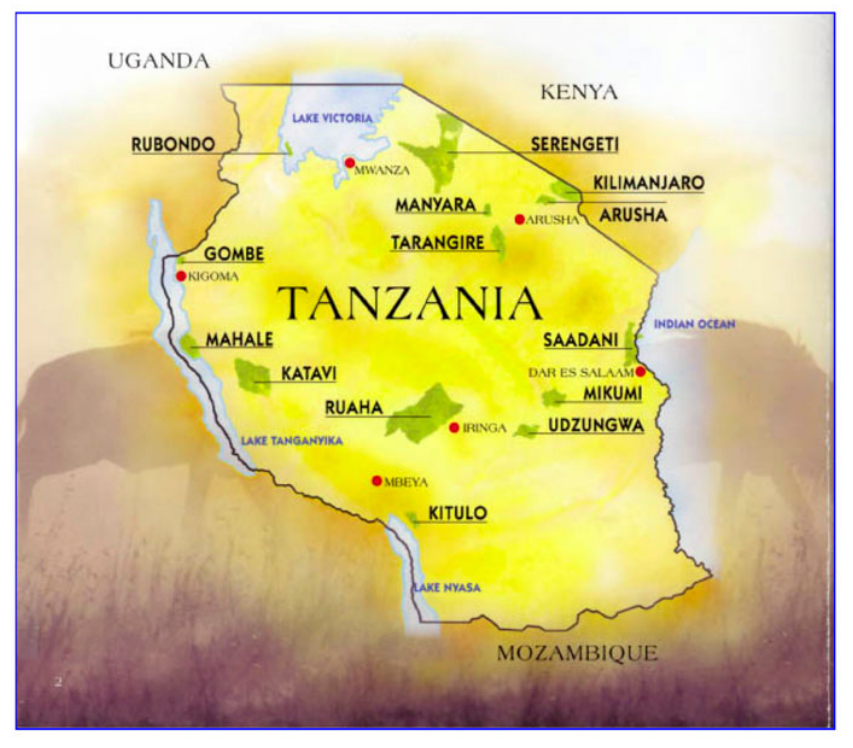

The relocation of people to give way to the expansion of the RNP produced a microcosm of management challenges that are evidenced in the broader management of social-ecological systems. On the one hand, the local villagers, who were relocated, perceived that the process of estimating and allocating compensation was not transparent. According to these villagers, national regulations governing forced relocation were also not observed and the relocated people were impoverished. A local respondent, for example, stated in an interview: "We are denied permanent employment opportunities at the park, our people remain for years with piece rate jobs - we think tribalism is the case." Another respondent stated: "By and large, we consider ourselves unlucky by residing close to the park because our fishing, hunting, and farming activities have been negatively affected." On the other hand, a representative of the national government during a workshop contested these perceptions of the local community disenchantment with the expansion of RNP. The national government representative argued that a fair compensation was provided to the local communities who were relocated.

Multiple ecological factors have been cited for elevating Usangu Game Reserve to the National Park status and annexing it with RNP, each of which has differential implications for the generation of winners and losers at multiple spatial scales. First, the management of Greater Ruaha watershed, which generates a significant amount of hydropower for the national government, was perceived to be threatened by keeping neighboring Usangu as a game reserve. Second, the expanded boundaries of RNP made it the largest national park in Tanzania, which was arguably better for the conservation of biodiversity. Third, this annexation could potentially improve the deteriorating wetlands of Usangu from environmental degradation.

Local communities appear to have negative attitudes toward conservation for a variety of reasons, such as the restrictions imposed by the protected area authorities that deny local communities access and user rights on natural resources for agriculture and livestock production. The relocation/eviction of villagers, according to these local communities, resulted in the loss of arable land, settlements, and livestock during the eviction process, and the eviction process interfered with their cultural and traditional beliefs and rituals. Furthermore, the local community respondents asserted that the national government did not assist in making the new village settlements conducive for human habitation such as providing social amenities, e.g., schools, water, and dispensary. The government promised to do this, but these promises have remained virtually unfulfilled, according to the local villagers interviewed. The national government representative denied these charges.

The Usangu-Ruaha conflict mirrors the larger conservationdevelopment conflict for the management of social-ecological systems at the global scale. Many of these conflicts arise in the postcolonial context of historical grievances and contestations of benefits sharing among social organizations at different spatial scales. The conservation community has for decades struggled with, and argued over, the spatial distribution of costs and benefits that accrue from natural resource conservation practices such as the eviction of local communities from the expansion of RNP (Adams and McShane 1996, Songorwa 1999, Agrawal and Redford 2006, Brockington et al. 2006, Wilkie et al. 2010). The costs of conservation actions, e.g., evictions of local communities, are imposed on local and indigenous communities while national and international communities enjoy the benefits of ecological conservation. Conversely, political economists have argued that the environmental costs of open-ended development actions, i.e., extinction of animals and plants, are also typically imposed on local and indigenous communities while national and international communities enjoy the benefits of globalization and economic development. This leads to a more general hypothesis that larger scale social organizations derive higher net benefits from pure conservation or pure development management options whereas smaller scale social organizations derive lower net benefits from such 
"pure" management options. In this study, we focus on estimating multicriteria and multiscalar value functions for conservation, development, and other "mixed" management options, with particular emphasis on the valuation differences across spatial scales. In particular, we explore the following hypotheses with respect to the conservation management option:

- Null Hypothesis: The management option of ecological conservation through national parks provides equal value to local, national, and international level social organizations.

- Alternate Hypothesis: The management option of ecological conservation through national parks provides higher value to international, followed by national, and least of all local level social organizations.

Conservation that requires eviction of local/indigenous communities for the protection of biodiversity is only one of the many available management options. Similarly, at the other end of the conservation-development spectrum, development that causes extinction or degradation of biodiversity is also only one of the many available management options. There are other mixed management options that can potentially be more responsive to the pluralistic values of local and indigenous communities as well as provincial and national level governments. Buffer zones and multiuse management options provide alternate mixed development paths to the one envisioned under either pure conservation or pure development management options. A key question is how a government should evaluate these alternate management options. We describe a deliberative multicriteria decision analysis (MCDA) approach that was used to gain insight into the estimation of cross-scale valuation trade-offs for alternate management scenarios of RNP. The limitations of this approach are also discussed as well as the results and the discussion of these results in terms of politics of scale.

\section{METHODS}

\section{Theoretical approach}

In recent literature on environmental policy and socialecological systems (Vatn and Bromley 1994, Bromley 1998, Norton and Steinemann 2001, Vatn 2002, Norton and Noonan 2007, Norgaard 2010), there appears to be an emerging consensus to use "development paths" as a unit of analysis for evaluating alternate management options. For example, outlining the elements of a deliberative pluralistic, multiscalar (DPM) theory of ecological valuation, Norton and Noonan (2007:672) suggested:

Development paths are ways our community/place can develop over time and into the future. Development paths can be thought of, alternatively, as scenarios, but here scenarios are used creatively and reflectively, to explore and evaluate possible development paths according to multiple criteria and not, as in economic models, as a methodological tool to measure welfare change. Proposed policies can be understood as interventions to modify or stabilize systemic effects on community or place, and simulations can be used to explore how policy options might lead to varied scenarios... Proposed policies, and the development paths they are modeled to shape and encourage, can then be evaluated on multiple criteria, including economic criteria (such as job creation and comparative efficiency of different institutional means to achieve improvements on key criteria), but also including longer-term impacts on ecological systems....In this way we can choose development paths to protect a range of human values, recognizing the multiple ways humans value nature.

MCDA enables elicitation of value trade-offs as a structured participatory mechanism for groups of multiple stakeholders to iteratively discuss incommensurate values and evaluate the weights on those values for choosing valuable actions. Building upon Norton and Noonan's (2007) idea of alternate development paths, we formally define a multicriteria expected value function $V_{i k}$ for $i^{\text {th }}$ development path in a set of $n$ development paths by $\mathrm{k}^{\text {th }}$ stakeholder as in equation 1 :

$$
\begin{aligned}
& V_{i k}=\sum_{i=1}^{n} w_{j k} x_{i j k} \\
& \text { s.t. } \sum_{j=1}^{m} w_{j k}=1
\end{aligned}
$$

Where $w_{j k}$ is a weighting or Trade-Off function for $j^{\text {th }}$ criterion in a set of $m$ criteria by $k^{\text {th }}$ stakeholder; and $x_{i j k}$ is an "outcome" or "impact" function for $i^{\text {th }}$ alternative on $j^{\text {th }}$ criteria as perceived by a $k^{\text {th }}$ stakeholder in a group of $K$ stakeholders for a set of $n$ alternatives. For an individual decision maker, the most valued development path is the one with the highest $V_{i k}$. A considerable challenge is how to aggregate $V_{i k}$ across groups of multiple stakeholders for choosing a development path that reflects the pluralistic values of all affected stakeholders. Formally, this aggregation challenge is represented through the assignment of $\Psi_{k}$ for aggregating $V_{i k}$ to estimate the societal value $V_{i}$ of $i^{\text {th }}$ development path, as shown in equation 2: 


$$
\begin{gathered}
V_{i}=\sum_{k=1}^{K} \Psi_{k} V_{i k} \\
\text { s.t. } \sum_{k=1}^{K} \Psi_{k}=1
\end{gathered}
$$

Substituting $V_{i k}$ from (1) in (2) yields equation 3:

$$
\begin{aligned}
& V_{i}=\sum_{k=1}^{K} \sum_{i=1}^{n} \Psi_{k} w_{j k} x_{i j k} \\
& \text { s.t. } \sum_{j=1}^{m} w_{j k}=1 \& \sum_{k=1}^{K} \Psi_{k}=1
\end{aligned}
$$

Equation 3 provides one of the many possible MCDA methods to assign multicriteria values on alternate development paths conditional upon the weights assigned to different stakeholders, the weights assigned by each stakeholder on different values in the system, as well as the impacts perceived by different stakeholders for each alternate development path vis-à-vis each value in the system. Here, we formally stipulate that a process issue in aggregation refers to how a stakeholder is included or excluded from the set of $K$ stakeholders. Furthermore, we define that a power issue in aggregation refers to the problem of assigning $\Psi_{k}$ weights to a $k^{\text {th }}$ stakeholder. In a perfectly egalitarian society, $\Psi_{k}$ will be equal for all stakeholders, which is rarely the case in real societies. Power asymmetries can be explicitly represented through the asymmetric assignment of $\Psi_{k}$. Because formal MCDA cannot endogenously determine $K$ and $\Psi_{k}$, we propose the deployment of deliberative and softer version of MCDA applications, as also argued by Martinez-Alier et al. (1998). In particular, we propose a continuous and iterative application of an open ended eight-step deliberative procedure, which is shown in Table 1, to estimate multicriteria value functions for alternate development paths as demonstrated in equation (3).

\section{Limitations: power dynamics and process issues}

Deliberative MCDA approach is designed to work best when processes entailing “ideal speech situations" (Habermas 1984, 1998) prevail. In real world situations, however, in particular those involving North-South dynamics with the history of colonization, we are often far from ideal speech situations. For example, ideal speech situations require that all participants be given a fair opportunity to participate and deliberate about their concerns in any given problematic situation. In real world situations, powerful participants may use explicit or implicit forms of power to influence the participation or the position of weaker participants.

Table 1. Procedural heuristic of deliberative MCDA.

\begin{tabular}{ll}
\hline \hline Steps & Procedures \\
\hline 1 & $\begin{array}{l}\text { Develop a group consensus on management scenarios } \\
\text { Develop a group consensus on criteria (mutually } \\
\text { exclusive and typically incommensurate) }\end{array}$ \\
3 & $\begin{array}{l}\text { Individuals assign weights on criteria } \\
\text { Individuals assign their perceived impacts on a } \\
\text { constructed scale for each scenario by each criterion } \\
\text { and scale }\end{array}$ \\
5 & $\begin{array}{l}\text { Individuals participate in small group discussion to } \\
\text { develop consensus on weights and perceived impacts }\end{array}$ \\
6 & $\begin{array}{l}\text { Workshop level weights and perceived impacts are } \\
\text { developed }\end{array}$ \\
Workshop level weights and perceived impacts are \\
multiplied to evaluate scenarios \\
The valuation process is repeated iteratively with \\
different set of stakeholder representatives
\end{tabular}

Deliberative MCDA methodologies also require extensive computational and cognitive skills to be implemented by the participants for authentic deliberations. In reality, as has been extensively demonstrated in decision theoretical research, many participants are averse to forcing themselves out of their comfort zones or routines and assigning constant-sum weights to values or comparing the impacts of different design options vis-à-vis different values. A more serious problem, known widely since the days of Howard Raifa (1968), concerns the assumption that values be mutually exclusive for assigning constant-sum weights. Although decision theorists have designed very sophisticated value mapping methods to implement the requirements of this value exclusivity assumption, it is very challenging and linguistically daunting to map exclusive values. When it comes to working across linguistic and cultural boundaries, such as the case of working in Africa, this kind of exclusive value enunciation challenge becomes even more intractable because of the politics of language and other power and process dynamic issues discussed above.

Messner (2006:164) summed up methodological problems with deliberative MCDA approaches: "what MCA method and which participatory approach should be selected for a certain evaluation problem? Who should determine the criteria? How is double counting prevented? Who decides on the weightings? Who is to be included in the participation process? How can objective results be attained?" Furthermore, aggregation issues, i.e., who should be assigned how much weight when aggregating value functions in a given problem solving 
situation, have posed difficult challenges for participatory and deliberative MCDA tools, as also discussed by Wilson and Howarth (2002) and Howarth and Wilson (2006). All of these, and other limitations discussed by Hisschenemoller and Hoppe (1995), Pellizzoni (2001), Shim et al. (2002), Stirling (2006), and Wittmer et al. (2006) are very tangible limitations of deliberative MCDA methodologies and utmost attention and caution must be observed while implementing such methods in field settings and interpreting the data from these deliberations for policy analytical purposes.

Notwithstanding these process and power dynamics, a number of studies have been published that demonstrate the applicability of a nonmonistic, value pluralistic, multicriteria theory of valuation with a Habermasian deliberative bent of communicative action (Martinez-Alier 2001, Wilson and Howarth 2002, Howarth and Wilson 2006, Klauer et al. 2006, Messner et al. 2006, Munda 2006, Norese 2006, Proctor and Dreschler 2006, Renn 2006, Stagl 2006, van den Hove 2006). This body of literature has emerged in parallel to the deliberative value focused decision analytic models (Keeney 1988, 1992, 1996, Gregory and Keeney 1994, Keeney and McDaniels 1999). Kiker et al. 2005 present a broad review of studies that involve the application of multiple criteria decision making models for environmental decision making.

\section{Data collection procedures}

A four-day research workshop was organized in Dar-esSalam, Tanzania in May 2009 to develop an integrative framework for negotiating trade-offs between conservation and development. The framework attempts to gain insight into complex conservation and development trade-offs by focusing analysis through three "integrative lenses" called, for short: valuation, process, and power (ACSC 2011). The approach described in this paper was an exercise in applying a valuation tool (MCDA) while paying explicit attention to the limitations of the application as a function of process and power issues.

The DPM theory of valuation (Norton 2005, Norton and Noonan 2007) was applied in the form of a deliberative MCDA exercise with 18 workshop participants during a four-hour session in the workshop. The 18 participants represented several disciplines from within academia, i.e., economics, political science, ecology, sociology, biology, anthropology, and relevant government and NGO representatives concerned about the management of RNP. The majority of the participants were part of a large interdisciplinary research team that had undertaken sociological, ecological, political, and economic research on various aspects of RNP on the case study site during the three years prior to the workshop. Representatives of local/national NGOs and relevant government ministries also had extensive background knowledge about the case study site at RNP.

Our focus in this paper is not on providing statistically valid results, because this study applies a deliberative MCDA methodology to elicit stakeholder values at multiple spatial scales for a test demonstration of the politics of scale in the management of social-ecological systems. More valid results will require iterative implementation of this methodology with all relevant RNP stakeholders, a task that could be accomplished in the follow up research. The statistical analysis reported here is for methodological demonstration purposes only and could be replicated in field settings. Instead of generalizability, our goal in this paper is to demonstrate the variability in the distribution of expected values across spatial scales under alternate management scenarios. We explicitly acknowledge that the process and power issues directly affect valuation, such as who is included and who is excluded from such deliberations. The estimated variability in the distribution of expected values across local, national, and international scales for alternate RNP management options serves to elucidate the politics of scale in conservation-development trade-offs enacted through public policies and institutional designs.

To contextualize the MCDA discussion for RNP, the moderators (two of the authors) began the discussion by focusing upon different management and design alternatives for managing various socioeconomic and ecological problems of the case study site (step 1 in Table 1). Five management alternatives were consensually chosen as alternatives for multicriteria evaluation. These alternatives were:

1. National park (business-as-usual scenario)

2. Game reserve area

3. Game control area

4. Multiple use area

\section{Open area}

Each of these management alternatives represents an alternate development path that can unfold in the park with appropriate environmental policy shifts at local, national, and international scales of governance. The first development path is the business-as-usual scenario, which requires no policy change. For the case of RNP, the system boundaries are currently designated as national park. The other four management options are practically a mix of conservation-development or purely development options, somewhat similar to the IUCN categorization of land-uses in biodiversity hotspots. The five categories used in this study have some similarities but also some major differences from the six categories used by IUCN (www.iucn.org/about/work/programmes/pa/pa products/ wcpa categories/). IUCN six categories are (1a) strict nature reserve; (1b) wilderness area; (2) national park; (3) natural monument; (4) habitat/species management area; (5) protected landscape/seascape; and (6) managed resource protected area. This study's categories are (1) national park, similar to IUCN category 2; (2) game reserve and (3) game control area, both 
of which are modified versions of IUCN category 4; (4) multiple use area, similar to IUCN category 6; and (5) open area, which is not one of the IUCN categories. Note that IUCN categories 1a, 1b, 3 and 5 are not included in this study.

Game reserve and game control areas allow exploitation of animals as hunting game in future or present time frames, respectively. Multiple use area allows some areas of the park to be opened up to various development activities, e.g., tourism, mining, energy, while other areas are conserved. For the fifth alternative, conservation requirements are totally abandoned and park area is declared open to any economic and/or anthropogenic exploitation. Notably, local communities, which in the National Park scenario were required to emigrate out of park boundaries, are not required to emigrate in the last three management options.

Next (step 2 in Table 1), a group consensus was developed on the multiple criteria for evaluation of these management options. The following six criteria were consensually agreed upon:

\section{Economic welfare (GDP/Capita)}

7. Good governance

8. Socio-cultural values

9. Social equity

10. Ecosystem services

11. Biodiversity protection

Because we were especially interested in scale issues pertaining to different valuation criteria, for step 3 in table 1 , participants were asked to individually mull over and fill in their constant sum weights for each of these six criteria along three spatial scalar dimensions: local, national, and international. Temporal scales were not included in this particular application because of a shortage of available time, but they can be added in future applications. An interactive survey form, as shown in Table 2, was handed over to the individuals for weighting. The participants were instructed to assign higher weight (in \%) to the valuation criteria that were more important to them or they cared more about, and lesser weight (in \%) to the criteria that they cared less about for the relevant spatial scale, with the constraint that all the weights must add up to $100 \%$. Of the 18 participants, 6 participants' individually assigned weights did not add up to 100 (a range of 95 and 118), and were rescaled to $100 \%$ for statistical analysis.

Figure $2 \mathrm{a}$ shows the constant sum weights that were elicited from 18 participants at the individual level. Biodiversity protection, ecosystem services, and economic welfare at the local scale were most highly valued by the participants, as shown by relatively higher weights assigned to these criteria in Figure 2a, whereas socio-cultural values, social equity, and economic welfare at the international scale were least valued by the participants. In other words, participants at the individual level were willing to trade off socio-cultural values and social equity at all spatial scales for the protection of biodiversity and ecosystem services. Economic welfare at local and national levels was also weighted relatively high, typically higher than good governance and social equity, but lower than biodiversity protection.

Table 2. Weighting Matrix: respondents were asked to assign weight from $0 \%$ to $100 \%$ for each value dimension, so that the total adds up to $100 \%$. The third column shows the means and standard deviations in () from the individual level workshop respondents $(\mathrm{N}=18)$.

\begin{tabular}{lcc}
\hline \hline Values & $\begin{array}{c}\text { Spatial } \\
\text { Dimension }\end{array}$ & $\begin{array}{c}\text { Assign Weight } \\
(0 \text { to } 100 \%)\end{array}$ \\
\hline Economic welfare (GDP/Capita) & Local & $9.04(9.06)$ \\
& National & $8.27(4.93)$ \\
& International & $0.75(1.36)$ \\
& & \\
Good Governance & Local & $5.79(5.46)$ \\
& National & $5.65(2.84)$ \\
& International & $2.82(3.33)$ \\
& & \\
Socio-cultural Values & Local & $6.42(5.03)$ \\
& National & $2.51(2.90)$ \\
& International & $1.24(2.39)$ \\
& & \\
Social Equity & Local & $5.52(4.09)$ \\
& National & $4.04(3.98)$ \\
& International & $0.83(1.71)$ \\
& & \\
Ecosystem Services & Local & $8.36(7.41)$ \\
& National & $8.27(6.03)$ \\
& International & $4.14(3.64)$ \\
& & \\
& Local & $11.64(20.18)$ \\
Biodiversity Protection & National & $7.67(5.62)$ \\
& International & $7.04(5.35)$
\end{tabular}

Total

$100 \%$

The 18 participants were subdivided into four groups for intense deliberation about the weights and perceived outcomes (step 5 in Table 1). The groups were labeled as (1) ecological group, because it had mostly ecologists and biologists; (2) national group, because it had government officials and researchers working at the national level; (3) socioeconomic and political group, because it had sociologists, economists, and political scientists; and (4) international group, because it had international participants.

For filling group level weights, participants were allowed to keep their individually filled survey forms (Table 2) in front of them while deliberating about assigning weights and 
Fig. 2. Predeliberative (panel a) and postdeliberative (panel b) weights elicited for valuation criteria, distributed by spatial scale: error bars show $95 \%$ confidence interval around mean.

\section{Pre-deliberative Individual Level}

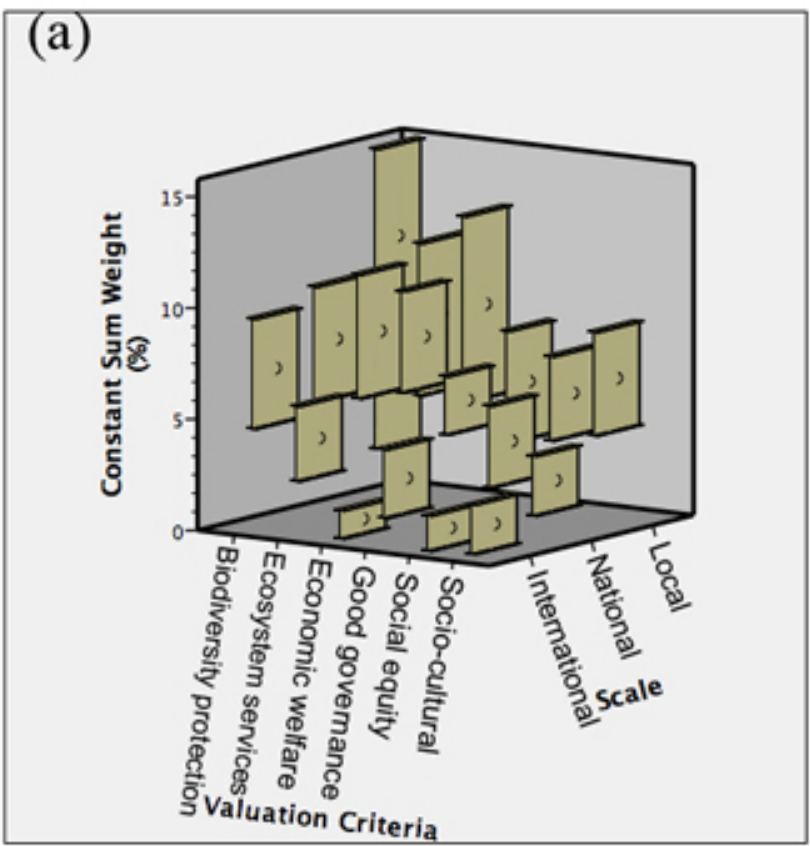

Post-deliberative Group Level

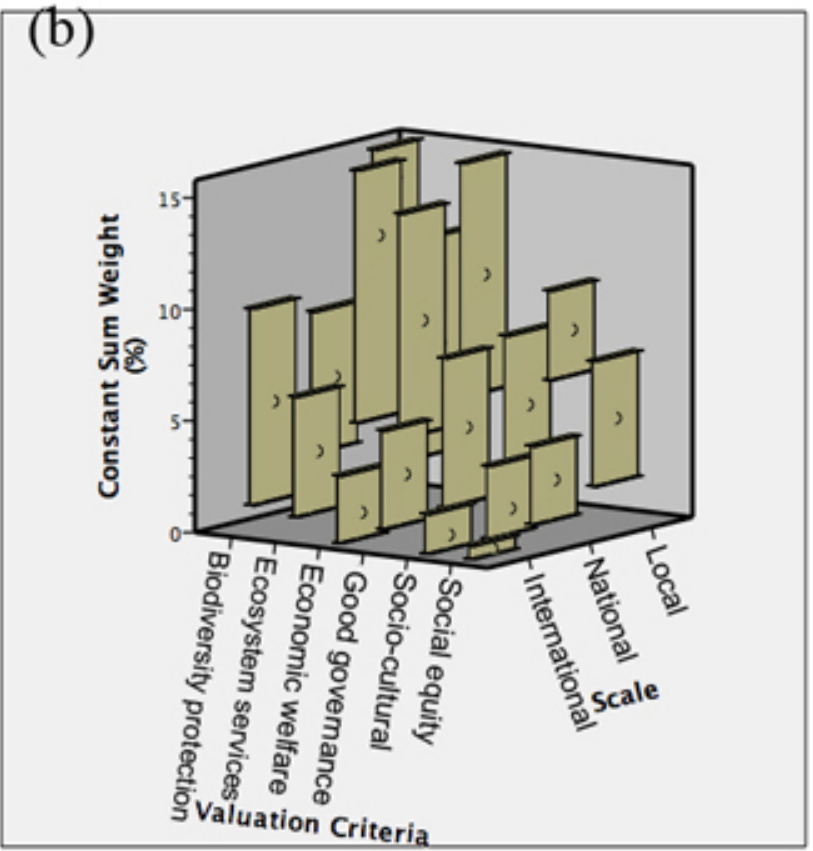

working to develop a group consensus. Figure $2 \mathrm{~b}$ shows the group level weights assigned by the participants after deliberation. Clearly, the variance in figure $2 b$ is much higher than figure $2 \mathrm{a}$, which shows the level of dissent among the participants within and across the groups. The averages of the assigned weights appear to be very similar after the deliberation. However, there are some important differences. First, social equity at the local scale was assigned higher weight after the group deliberation, whereas good governance at the local scale was assigned relatively lower weight (figure $2 b$ ), as compared with the predeliberation weights (figure $2 a$ ). Second, biodiversity protection at the local scale and ecosystem services at local and national scales were assigned relatively higher weight in predeliberative individual level (figure $2 \mathrm{a}$ ), but economic welfare at the national scale was assigned even higher weight than biodiversity protection and ecosystem services after the group deliberation (figure $2 b$ ). These differences are not statistically significant, presumably because of smaller sample size, but slight shifts in average weights did happen after the deliberation, though larger pattern of trade-offs among the valuation criteria did not change.

Prior to congregating participants in groups, an impact evaluation matrix (Table 3) was also provided to the workshop participants for filling in, first at individual levels, and then in deliberative groups. For this impact evaluation matrix, the participants were asked to assess the impact of each scenario vis-à-vis each of the seven criteria at three spatial scales on a constructed scale. A normalized constructed scale was used for all scenarios and criteria so the participants could focus on the spatial asymmetric impacts of alternate management scenarios. The constructed scale ranged from a value of 0 (adverse impact) to 100 (best impact), as shown in Table 3. For example, in the first top left empty cell, as explained to participants, they judged the economic welfare impact at local scale if the business-as-usual (national park) management alternative was continued, and so on for the other cells in the impact evaluation matrix. In future extensions of this methodology, environmental impact assessment and strategic impact assessment studies can be combined with the proposed deliberative MCDA methodology to incorporate uncertainty information about the impacts of alternate management options at various scales (for an example, please see Klauer et al. 2006). However, such multiscale impact assessment studies require a large amount of financial and human resources, and face complex cognitive and computational limitations when impact assessment data is normalized, e.g., through linear or vector normalization procedures. In contrast, the constructed scale methodology deployed in this study is cost-effective and readily incorporates the perceptions of multiple stakeholder groups, which is different from the 
Table 3. Impact Evaluation Matrix: respondents were asked to assign a value of 0 (adverse impact) to 100 (best impact) for each cell, row by row. The cells show the means and standard deviations in () from the individual level workshop respondents $(\mathrm{N}=$ 18).

\begin{tabular}{|c|c|c|c|c|c|c|}
\hline Values & Spatial Dimension & National Park & Game Reserve & $\begin{array}{c}\text { Game } \\
\text { Controlled } \\
\text { Area }\end{array}$ & $\begin{array}{l}\text { Multiple Use } \\
\text { Area }\end{array}$ & Open Area \\
\hline \multirow[t]{3}{*}{$\begin{array}{l}\text { Economic welfare (GDP/ } \\
\text { Capita) }\end{array}$} & Local & $\begin{array}{c}12.50 \\
(13.95)\end{array}$ & $\begin{array}{c}21.50 \\
(15.35)\end{array}$ & $\begin{array}{c}37.50 \\
(18.80)\end{array}$ & $\begin{array}{c}53.06 \\
(26.13)\end{array}$ & $\begin{array}{c}60.56 \\
(37.33)\end{array}$ \\
\hline & National & $\begin{array}{c}72.50 \\
(22.96)\end{array}$ & $\begin{array}{c}63.06 \\
(22.50)\end{array}$ & $\begin{array}{c}46.39 \\
(21.20)\end{array}$ & $\begin{array}{c}42.22 \\
(25.79)\end{array}$ & $\begin{array}{c}31.39 \\
(25.99)\end{array}$ \\
\hline & International & $\begin{array}{c}39.72 \\
(28.51)\end{array}$ & $\begin{array}{c}35.56 \\
(31.14)\end{array}$ & $\begin{array}{c}21.94 \\
(20.59)\end{array}$ & $\begin{array}{c}19.39 \\
(19.59)\end{array}$ & $\begin{array}{c}10.06 \\
(13.37)\end{array}$ \\
\hline \multirow[t]{3}{*}{ Good Governance } & Local & $\begin{array}{c}29.44 \\
(26.22)\end{array}$ & $\begin{array}{c}31.94 \\
(23.46)\end{array}$ & $\begin{array}{c}42.50 \\
(23.21)\end{array}$ & $\begin{array}{c}51.39 \\
(31.75)\end{array}$ & $\begin{array}{c}47.00 \\
(36.91)\end{array}$ \\
\hline & National & $\begin{array}{c}50.83 \\
(31.58)\end{array}$ & $\begin{array}{c}46.67 \\
(29.30)\end{array}$ & $\begin{array}{c}47.22 \\
(27.61)\end{array}$ & $\begin{array}{c}55.56 \\
(28.64)\end{array}$ & $\begin{array}{c}41.94 \\
(35.65)\end{array}$ \\
\hline & International & $\begin{array}{c}48.89 \\
(30.70)\end{array}$ & $\begin{array}{c}40.56 \\
(25.66)\end{array}$ & $\begin{array}{c}33.89 \\
(27.36)\end{array}$ & $\begin{array}{c}27.22 \\
(19.79)\end{array}$ & $\begin{array}{c}14.67 \\
(19.30)\end{array}$ \\
\hline \multirow[t]{3}{*}{ Socio-cultural Values } & Local & $\begin{array}{c}27.33 \\
(34.89)\end{array}$ & $\begin{array}{c}31.39 \\
(27.69)\end{array}$ & $\begin{array}{c}47.22 \\
(27.61)\end{array}$ & $\begin{array}{c}64.44 \\
(23.06)\end{array}$ & $\begin{array}{c}63.33 \\
(31.90)\end{array}$ \\
\hline & National & $\begin{array}{c}25.83 \\
(27.66)\end{array}$ & $\begin{array}{c}33.61 \\
(23.75)\end{array}$ & $\begin{array}{c}33.33 \\
(24.07)\end{array}$ & $\begin{array}{c}44.17 \\
(31.91)\end{array}$ & $\begin{array}{c}36.28 \\
(35.68)\end{array}$ \\
\hline & International & $\begin{array}{c}25.28 \\
(28.97)\end{array}$ & $\begin{array}{c}22.72 \\
(26.90)\end{array}$ & $\begin{array}{c}22.50 \\
(23.02)\end{array}$ & $\begin{array}{c}24.17 \\
(29.71)\end{array}$ & $\begin{array}{c}18.17 \\
(32.30)\end{array}$ \\
\hline \multirow[t]{3}{*}{ Social Equity } & Local & $\begin{array}{c}8.61 \\
(11.48)\end{array}$ & $\begin{array}{c}18.06 \\
(17.99)\end{array}$ & $\begin{array}{c}39.44 \\
(25.60)\end{array}$ & $\begin{array}{c}58.33 \\
(25.14)\end{array}$ & $\begin{array}{c}60.94 \\
(29.80)\end{array}$ \\
\hline & National & $\begin{array}{c}36.11 \\
(28.98)\end{array}$ & $\begin{array}{c}32.22 \\
(22.37)\end{array}$ & $\begin{array}{c}36.78 \\
(23.95)\end{array}$ & $\begin{array}{c}45.89 \\
(27.30)\end{array}$ & $\begin{array}{c}34.61 \\
(29.77)\end{array}$ \\
\hline & International & $\begin{array}{c}30.44 \\
(30.78)\end{array}$ & $\begin{array}{c}36.61 \\
(26.90)\end{array}$ & $\begin{array}{c}38.44 \\
(22.22)\end{array}$ & $\begin{array}{c}40.94 \\
(32.63)\end{array}$ & $\begin{array}{c}29.00 \\
(36.05)\end{array}$ \\
\hline \multirow[t]{3}{*}{ Ecosystem Services } & Local & $\begin{array}{c}53.61 \\
(33.72)\end{array}$ & $\begin{array}{c}48.61 \\
(32.16)\end{array}$ & $\begin{array}{c}61.39 \\
(27.59)\end{array}$ & $\begin{array}{c}62.50 \\
(29.86)\end{array}$ & $\begin{array}{c}45.61 \\
(34.04)\end{array}$ \\
\hline & National & $\begin{array}{c}72.50 \\
(22.96)\end{array}$ & $\begin{array}{c}60.56 \\
(25.31)\end{array}$ & $\begin{array}{c}57.78 \\
(24.08)\end{array}$ & $\begin{array}{c}43.89 \\
(29.53)\end{array}$ & $\begin{array}{c}24.44 \\
(28.52)\end{array}$ \\
\hline & International & $\begin{array}{c}67.72 \\
(36.28)\end{array}$ & $\begin{array}{c}51.56 \\
(31.24)\end{array}$ & $\begin{array}{c}44.83 \\
(23.32)\end{array}$ & $\begin{array}{c}28.78 \\
(19.81)\end{array}$ & $\begin{array}{c}19.33 \\
(20.25)\end{array}$ \\
\hline \multirow[t]{3}{*}{ Biodiversity Protection } & Local & $\begin{array}{c}57.22 \\
(39.07)\end{array}$ & $\begin{array}{c}50.28 \\
(32.69)\end{array}$ & $\begin{array}{c}48.06 \\
(27.07)\end{array}$ & $\begin{array}{c}52.50 \\
(30.54)\end{array}$ & $\begin{array}{c}30.11 \\
(35.79)\end{array}$ \\
\hline & National & $\begin{array}{c}80.28 \\
(22.45)\end{array}$ & $\begin{array}{c}68.06 \\
(22.03)\end{array}$ & $\begin{array}{c}50.83 \\
(23.02)\end{array}$ & $\begin{array}{c}41.94 \\
(26.41)\end{array}$ & $\begin{array}{c}18.33 \\
(25.78)\end{array}$ \\
\hline & International & $\begin{array}{c}78.56 \\
(31.09)\end{array}$ & $\begin{array}{c}67.11 \\
(28.45)\end{array}$ & $\begin{array}{c}46.11 \\
(25.65)\end{array}$ & $\begin{array}{c}38.11 \\
(28.42)\end{array}$ & $\begin{array}{c}12.22 \\
(16.46)\end{array}$ \\
\hline
\end{tabular}

expert-system based approaches that are generally used in impact assessment studies. Furthermore, assessment of impacts for qualitative criteria such as good governance, socio-cultural values, or social equity inevitably requires generation of proxy attributes and constructed scales.

Figure 3 shows the impact evaluation matrices for each of the five management options in five panels, as perceived by participants at the individual level prior to group deliberation. There are some interesting discernible patterns that emerge from the comparison of the five panels of Figure 3. For the management option of national park (Figure 3a), participants perceived much better impacts (closer to 100) for biodiversity protection and ecosystem services, especially at international and national scales, but the impacts on socio-cultural values and social equity were considered to be more adverse (closer to 0 ). These differences are statistically significant. National park status is perceived to have a better impact for economic welfare at the national scale but the local scale is perceived to suffer very adverse economic welfare impact from keeping Ruaha as a national park.

In contrast, Figure $3 \mathrm{e}$ shows the perceived impacts when RNP is declared open area: biodiversity protection, ecosystem 
Fig. 3. Predeliberative impacts by valuation criteria and spatial scale for national park (panel a), game reserve (panel b), game control area (panel c), multiple use area (panel d), and open area (panel e) options. Impacts are measured on a continuous scale from $0 \%$ adverse to $100 \%$ best impact.

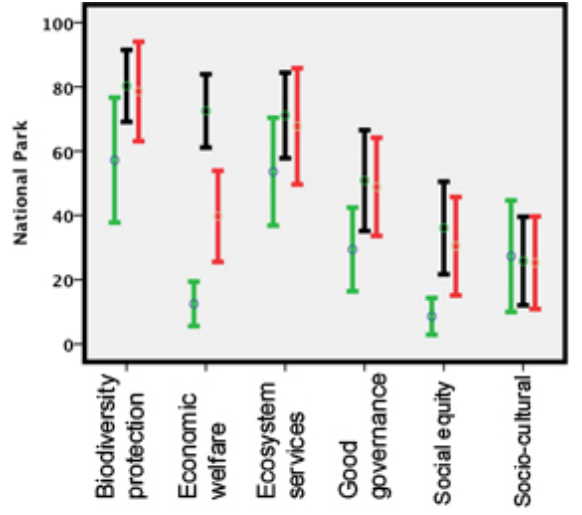

Decision Criteria

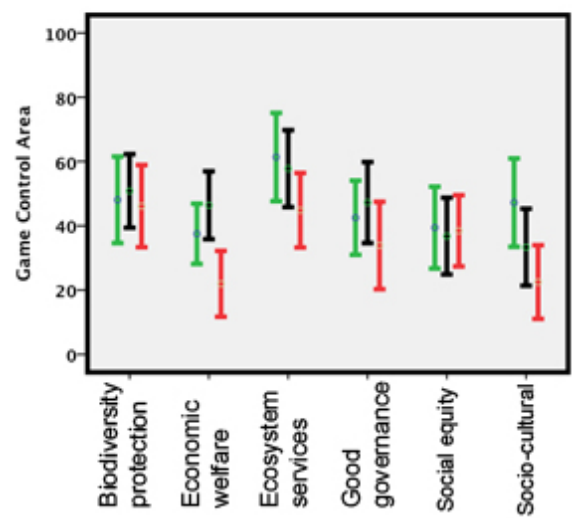

Decision Criteria

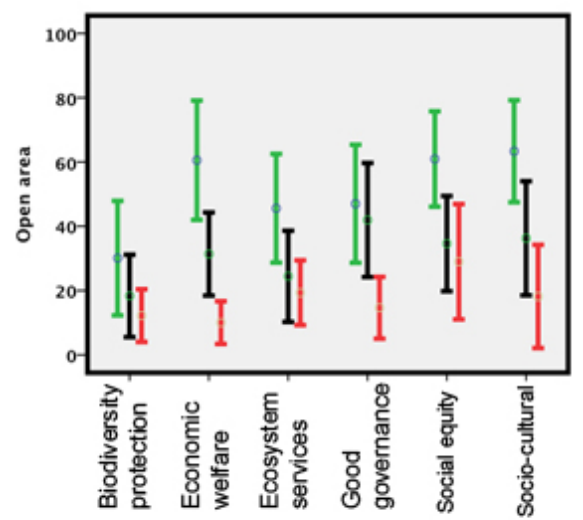

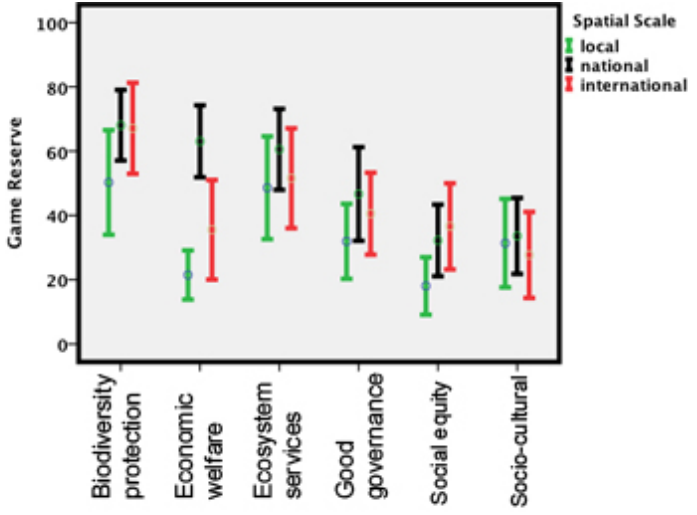

Decision Criteria

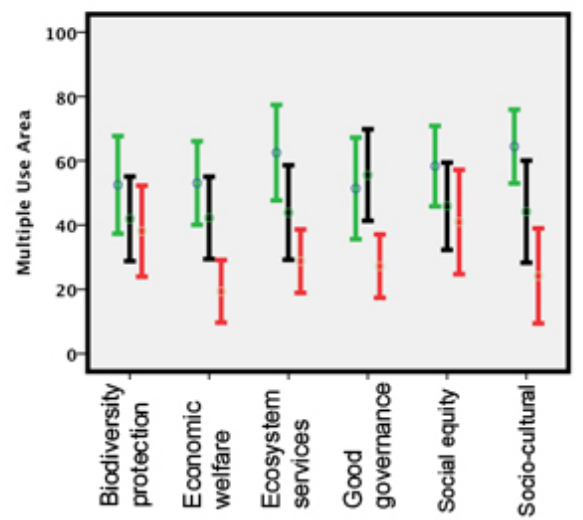

Decision Criteria 
services, and economic welfare at the international scale are perceived to suffer the worst impacts from changing RNP to the open area category. However, participants perceived that this management scenario would have very positive impact on economic welfare, social equity, and the protection of socio-cultural values at the local scale. The management option of multiple use area (Fig. 3d) shows an interesting pattern of perceived impacts: although this management option will have significantly adverse impact on the protection of biodiversity and ecosystem services at the international scale, participants perceive that this option will have a very positive impact on the protection of ecosystem services and socio-cultural values at the local scale. National scale level impacts fall between local and international scales, as shown in figure $3 \mathrm{~d}$. Similar patterns can be assessed in figures $3 \mathrm{~b}$ and $3 \mathrm{c}$ for the management options of game reserve and game controlled areas. Overall, the workshop participants appear to have a consistent and sharper perception of the impacts on the valuation criteria when different management options are pursued. Larger sample size in follow-up studies will probably further narrow the confidence intervals of these perceived impacts. Group level perceived impacts (not shown here because of paucity of space) are very similar to the individual level perceived impacts (Fig. 3).

\section{RESULTS}

Although an intergroup level discussion can be carried out to resolve the conflict at the workshop level, which we did not carry out because of time shortage, we believe "aggregation" of individual and group level results is an intransigent issue from the politics of scale perspective. This is an especially intransigent problem because it is very difficult to decide whose preference should be given how much weight in the final aggregation: should representatives of international institutions be given as much weight as national level policy makers or should local communities be given more weight? Our proposed methodology enables explicit analysis of this politics of scale and renders transparent the value preferences of actors from social organizations at multiple scales.

If we assign equal weight to each participant at individual and group levels and aggregate their expected values, as shown in Figure 4, we find that individual participants placed the highest expected value for multiple use area, followed by national park, game reserve, game control, and open area, respectively. However, at the group level, national park has a slightly higher expected value than the multiple use area, and both dominate the other three management options. We thus find that individual level predeliberative MCDA seems to produce different results than the group level postdeliberative MCDA.

The five panels of Figure 5 show the expected value results from the predeliberative workshop data to test the spatial scale hypothesis. From the demonstrative workshop results, we reject the null hypothesis that the management option of conservation provides equal value to local, national, and international communities. Figure 5a shows predeliberative value for the national park management option for each valuation criterion and spatial scale. The management option of conservation provides higher value to international, followed by national, and least of all local communities. In contrast, the management options of multiuse area (figure 5d) and open area (figure 5e) are perceived by the workshop participants to provide highest value on all valuation criteria at the local scale and the least value at the international scale.

Fig. 4. Valuation of alternate development paths, aggregated at individual (predeliberative) and group (postdeliberative) levels.

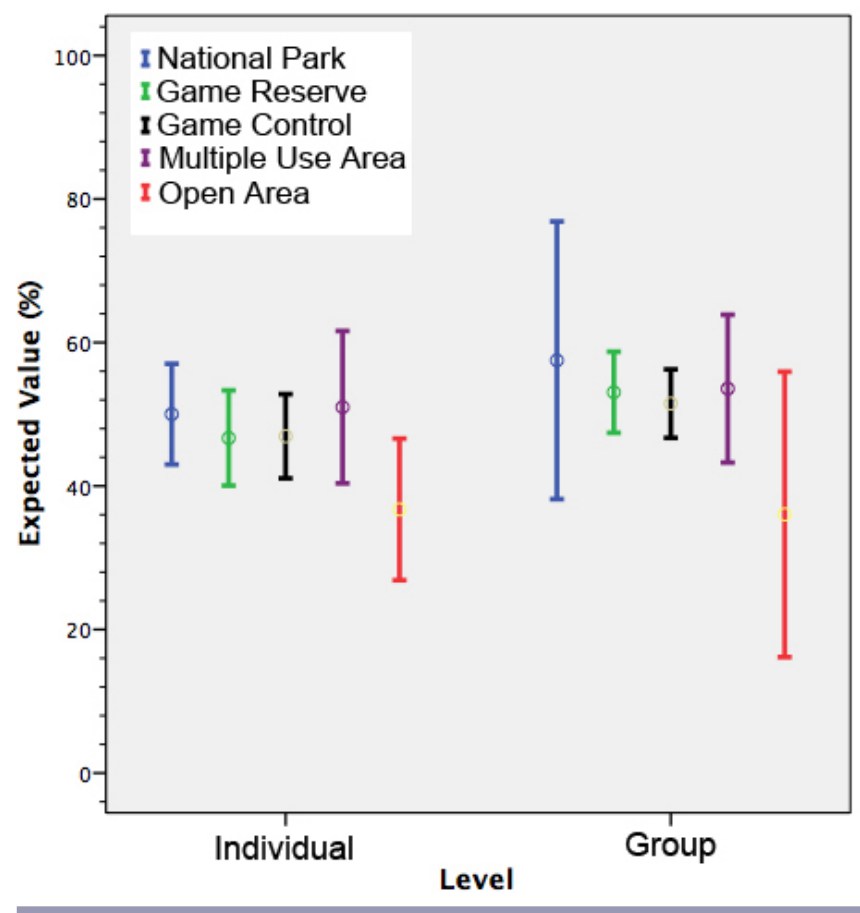

\section{DISCUSSION}

The demonstrative application of the proposed participatory MCDA methodology for eliciting value trade-offs at multiple spatial scales shows that the current management option of conservation at RNP is perceived to provide higher value to international and national level stakeholder groups while local communities living adjacent to the national park receive much less value. This demonstrative result is hardly surprising and is the subject of numerous other types of research concerning conservation and its relationship to rural communities, and the numerous interventions attempting to address such discrepancies (Agrawal and Gibson 1999, Hulme and Murphree 2001, Brokington and Schmidt-Soltau 2004, Wells and McShane 2004, Sunderland et al. 2008). However, the 
Fig. 5. Predeliberative expected value by valuation criteria and spatial scale for national park (panel a), game reserve (panel b), game control area (panel c), multiple use area (panel d), and open area (panel e) options.

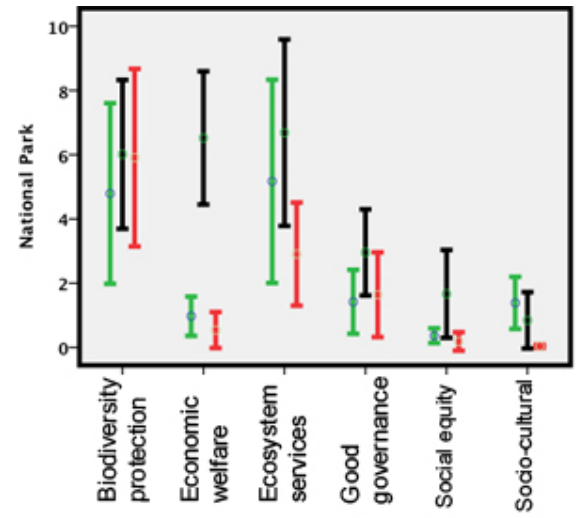

Decision Criteria

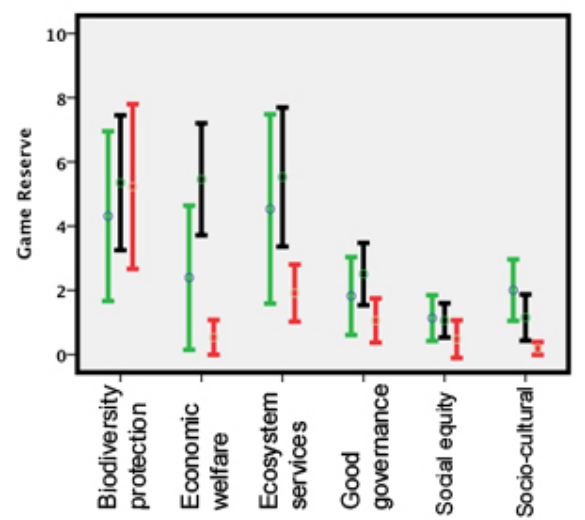

Decision Criteria

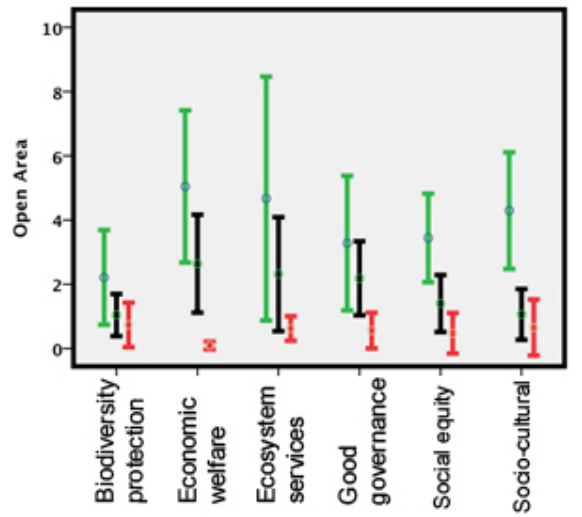

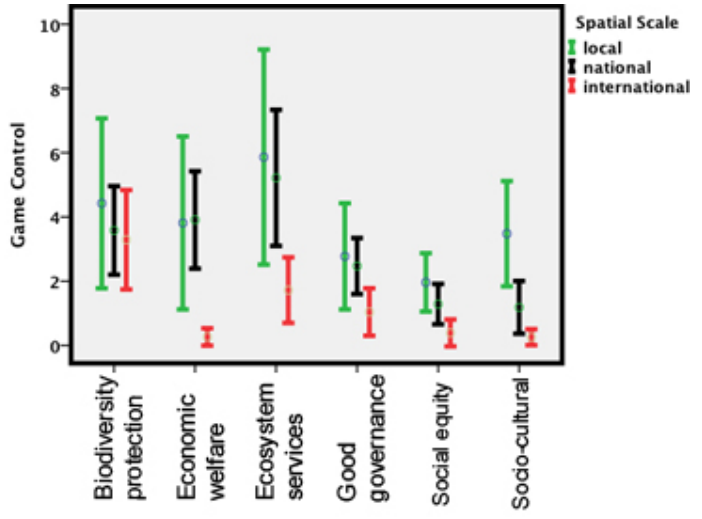

Decision Criteria

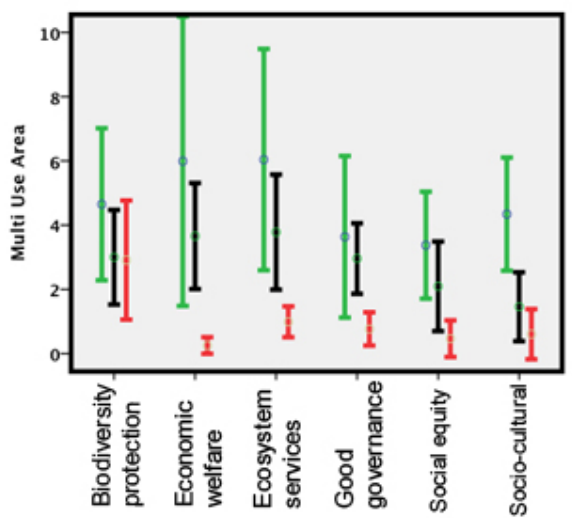

Decision Criteria 
connection of this spatial valuation discrepancy with politics of scale literature is novel. Furthermore, the proposed deliberative methodology provides a participatory mechanism for a large number of stakeholder groups to engage in structured discussions for elucidating and quantifying crossscale trade-offs. Therefore, from the demonstrative application of this participatory methodology, we find that although workshop participants were willing to trade off local level social equity and socio-cultural values for the long-term protection of biodiversity and ecosystem services, promotion of economic growth at local and national levels is also considered important by the workshop participants. The management option of a multiuse area for RNP elicits the highest value (on an individual aggregation basis), whereas the management option of keeping RNP as a national park is favored by two out of four groups (on group level aggregation). Multiuse and game reserve management options are favored by two other groups. The elicitation of value trade-offs at multiple spatial scales provides sufficient information to warrant additional research with multiple stakeholder groups to assess the viability of current management of RNP and devise alternate management plans that balance multiple values.

The current management scenario at RNP provides an insight into the politics of scale that is symptomatic of many similar conservation type management scenarios in both developing and developed countries. Transparent explication of spatial distribution of value trade-offs enables an integrative analysis to identify and discuss alternate management options that could potentially balance the current politics of scale back toward local level social organizations. When policies are extreme versions of open-ended development, or on the opposite end, an extreme version of regulated conservation, larger scale social organizations appear to derive higher value whereas smaller scale social organizations derive lesser value. Because both explicit and implicit forms of power are available to social organizations at larger scales, we observe this type of politics of scale in the management of many different kinds of social-ecological systems that are similar to RNP. In contrast, the politics of scale could be potentially mediated by designing nonextreme policies that balance conservation and development goals. Further, quantification of cross-scale value distributions could also provide insight regarding the appropriate magnitude and direction of payments for ecosystem services and other compensatory mechanisms from international and national level to local level social organizations in situations where balanced or mixed management approaches are not feasible, a topic that could be explored in future research.

\section{CONCLUSION}

We applied a deliberative and participatory multicriteria decision analytical approach to quantify cross-scale pluralistic value trade-offs for alternate management scenarios of socialecological systems. The elicitation of value trade-offs at multiple spatial scales was made operational in the context of management scenarios for Ruaha National Park in Tanzania. Although there are significant computational and cognitive limitations of applying such deliberative multicriteria decision analytical methodologies, making hard choices requires hard thinking and work in clarifying values, weighing values, and exploring potential impacts of different management scenarios at multiple spatial scales with respect to those weighted values. Recognition of multiple values, multiple scales, and the empowerment of local communities through deliberative mechanisms could be made operational by the deliberative MCDA methodology laid out in this study, and could provide a viable ecological valuation methodology for comparing management alternatives of social-ecological systems and mediating politics of scale in the management of social-ecological systems.

We demonstrated the variability, in some cases statistically significant, in expected values across spatial scales for different management scenarios. We explored the hypothesis that conservation-oriented management scenarios generate higher value for international and national scale social organizations, whereas mixed or more balanced management scenarios generate higher value for local scale social organizations. The asymmetric distribution of value at multiple spatial scales enables us to analyze the politics of scale that has resulted in the current management scenario at RNP and similar other social-ecological systems, which can be seen as serving the values of national and international levels of social organization, while the values of local levels of social organization are traded-off. The quantification of such cross-scale value trade-offs could provide useful information in the future for the design of policy mechanisms that transfer benefits from international and national to local levels of social organization and, hopefully, reverse the current course of politics of scale in managing social-ecological systems.

Responses to this article can be read online at: http://www.ecologyandsociety.org/voll6/iss4/art7/responses/

\section{Acknowledgments:}

We gratefully acknowledge the financial support provided by the John D. and Catherine T. MacArthur Foundation for the research project "Advancing Conservation in a Social Context: Working in a World of Trade-Offs" and James Jeffords Center of Policy Research at the University of Vermont.

\section{LITERATURE CITED}

Adams, J. S., and T. O. McShane. 1996. The myth of wild Africa: conservation without illusion. University of California Press, Berkeley, California, USA. 
Adger, W. N., K. Brown, and E. L. Tompkins. 2005. The political economy of cross-scale networks in resource comanagement. Ecology and Society 10(2): 9. [online] URL: http://www.ecologyandsociety.org/vol10/iss2/art9/

Advancing Conservation in a Social Context (ACSC). 2011. Advancing Conservation in a Social Context: Working in a World of Trade-offs. Final Report. Global Institute of Sustainability, Arizona State University, Tempe, AZ, USA. [online] URL: http://cicr.uga.edu/acsc/ACSC_final_report.pdf

Agnew, J. 1997. The dramaturgy of horizons: geographical scale in the "reconstruction of Italy" by the new Italian political parties, 1992-95. Political Geography 16(2):99-121. http://dx .doi.org/10.1016/S0962-6298(96)00046-7

Agrawal, A., and C. Gibson 1999. Enchantment and disenchantment: the role of community in natural resource conservation. World Development 27(4):629-649. http://dx.do i.org/10.1016/S0305-750X(98)00161-2

Agrawal, A., and K. H. Redford. 2006. Poverty, development and biodiversity conservation: shooting in the dark? Wildlife Conservation Society Working Paper No. 26. WCS, New York, New York, USA.

Berkes, F. 2002. Cross-scale institutional linkages for commons management: perspectives from the bottom up. Pages 293-321 in E. Ostrom, T. Dietz, N. Dolsak, P. C. Stern, S. Stonich, and E. U. Weber, editors. The drama of the commons. National Academy Press, Washington, D.C., USA.

Berkes, F. 2006. From community-based resource management to complex systems: the scale issue and marine commons. Ecology and Society 11(1): 45. [online] URL: http ://www.ecologyandsociety.org/vol11/iss 1/art45/

Brenner, N. 2001. The limits to scale? Methodological reflections on scalar structuration. Progress in Human Geography 25 (4):591-614. http://dx.doi.org/10.1191/030913 $\underline{201682688959}$

Brockington, D., J. Igoe, and K. Schmidt-Soltau. 2006. Conservation, human rights, and poverty reduction. Conservation Biology 20:250-252. http://dx.doi.org/10.1111/ j.1523-1739.2006.00335.x

Brockington, D., and K. Schmidt-Soltau. 2004. The social and environmental impacts of wilderness and development. Oryx 38:140-142. http://dx.doi.org/10.1017/S0030605304000250

Bromley, D. W. 1998. Searching for sustainability: the poverty of spontaneous order. Ecological Economics 24(2-3):231-240. http://dx.doi.org/10.1016/S0921-8009(97)00145-6

Brown, J. C., and M. Purcell. 2005. There's nothing inherent about scale: political ecology, the local trap, and the politics of development in the Brazilian Amazon. Geoforum 36:607-624. http://dx.doi.org/10.1016/j.geoforum.2004.09.001

Cash, D. W., W. Adger, F. Berkes, P. Garden, L. Lebel, P. Olsson, L. Pritchard, and O. Young. 2006. Scale and crossscale dynamics: governance and information in a multilevel world. Ecology and Society 11(2): 8. [online] URL: http://ww w.ecologyandsociety.org/vol11/iss2/art8/

Delaney, D., and H. Leitner. 1997. The political construction of scale. Political Geography 16 (2):93-97. http://dx.doi.org/ $\underline{10.1016 / \mathrm{S} 0962-6298(96) 00045-5}$

Escobar, A. 2001. Culture sits in places: reflections on globalism and subaltern strategies of localization. Political Geography 20:139-174. http://dx.doi.org/10.1016/S0962-6298 (00)00064-0

Gregory, R., and R. L. Keeney. 1994. Creating policy alternatives using stakeholder values. Management Science 40:1035-1048. http://dx.doi.org/10.1287/mnsc.40.8.1035

Habermas, J. 1984. The theory of communicative action. Beacon, Boston, Massachusetts, USA.

Habermas, J. 1998. Between facts and norms: contributions to a discourse theory of law and democracy. The MIT Press, Cambridge Massachusetts, USA.

Hirsch, P. D., W. M. Adams, J. P. Brosius, A. Zia, N. Bariola, and J. L. Dammert. 2011. Acknowledging conservation tradeoffs and embracing complexity. Conservation Biology 25:259-264.

Hisschenemoller, M., and R. Hoppe. 1995. Coping with intractable controversies: the case of problem structuring in policy design. Knowledge and Policy 95:1-18.

Howarth, R. B., and M. A. Wilson. 2006. A theoretical approach to deliberative valuation: aggregation by mutual consent. Land Economics 82:1-16.

Howitt, R. 1998. Scale as relation: musical metaphors of geographical scale. Area 30(1):49-58. http://dx.doi.org/10.1111/ j.1475-4762.1998.tb00047.x

Hulme, D., and M. W. Murphree, editors. 2001. Africa wildlife and livelihoods: the promise and performance of community conservation. James Currey, Oxford, UK.

Jonas, A. 1994. The scale politics of spatiality. Environment and Planning D: Society and Space 12:257-264.

Keeney, R. L. 1988. Building models of values. European Journal of Operational Research 37:149-157. http://dx.doi.or g/10.1016/0377-2217(88)90324-4

Keeney, R. L. 1992. Value focused thinking. Harvard University Press, Cambridge, Massachusetts, USA. 
Keeney, R. L. 1996. Value-focused thinking: identifying decision opportunities and creating alternatives. European Journal of Operational Research 92:537-549. http://dx.doi.or g/10.1016/0377-2217(96)00004-5

Keeney, R. L., and T. L. McDaniels. 1999. Identifying and structuring values to guide integrated resource planning at BC Gas. Operations Research 47:651-662. http://dx.doi.org/10.1 287/opre.47.5.651

Kiker, G. A., T. S. Bridges, A. Varghese, T. P. Seager, and I. Linkov. 2005. Application of multicriteria decision analysis in environmental decision making. Integrated Environmental Assessment and Management 1:95-108. http://dx.doi.org/10.1 897/IEAM 2004a-015.1

Klauer, B., M. Drechsler, and F. Messner. 2006. Multicriteria analysis under uncertainty with IANUS - method and empirical results. Environment and Planning C: Government and Policy 24:235-256. http://dx.doi.org/10.1068/c03102s

Lebel, L., P. Garden, and M. Imamura. 2005. The politics of scale, position, and place in the governance of water resources in the Mekong region. Ecology and Society 10(2): 18 [online] URL: http://www.ecologyandsociety.org/vol10/iss2/art18/

Marston, S. 2000. The social construction of scale. Progress in Human Geography 24(2):219-242. http://dx.doi.org/10.119 $\underline{1 / 030913200674086272}$

Martinez-Alier, J. 2001. Ecological conflicts and valuation: mangroves versus shrimps in the late 1990s. Environment and Planning C: Government and Policy 19:713-728. http://dx.do i.org/10.1068/c15s

Martinez-Alier, J., G. Munda, and J. O'Neill. 1998. Weak comparability of values as a foundation for ecological economics. Ecological Economics 26:277-286. http://dx.doi.o $\mathrm{rg} / 10.1016 / \mathrm{S} 0921-8009(97) 00120-1$

McShane, T. O., P. D. Hirsch, T. C. Trung, A. N. Songorwa, A. Kinzig, B. Monteferri, D. Mutekanga, H. V. Thang, J. L. Dammert, M. Pulgar-Vidal, M. Welch-Devine, J. P. Brosius, P. Coppolillo, and S. O'Connor. 2011. Hard choices: making trade-offs between biodiversity conservation and human wellbeing. Biological Conservation 144(3):966-972. http://dx.doi. org/10.1016/j.biocon.2010.04.038

Messner, F. 2006. Applying participatory multicriteria methods to river basin management: improving the implementation of the Water Framework Directive. Environment and Planning C: Government and Policy 24:159-167. http://dx.doi.org/10.1068/c2402ed

Messner, F., O. Zwirner, and M. Karkuschke. 2006. Participation in multi-criteria decision support for the resolution of a water allocation problem in the Spree River basin. Land Use Policy 23:63-75. http://dx.doi.org/10.1016/j. landusepol.2004.08.008
Munda, G. 2006. Social multi-criteria evaluation for urban sustainability policies. Land Use Policy 23:86-94. http://dx.d oi.org/10.1016/j.landusepol.2004.08.012

Norese, M. F. 2006. ELECTRE III as a support for participatory decision-making on the location of wastetreatment plants. Land Use Policy 23:76-85. http://dx.doi.org $\underline{\text { 10.1016/j.landusepol.2004.08.009 }}$

Norgaard, R. B. 2010. Ecosystem services: from eye-opening metaphor to complexity blinder. Ecological Economics 69 (6):1219-1227. http://dx.doi.org/10.1016/j.ecolecon.2009.11.009

Norton, B. G. 2005. Sustainability: a philosophy of adaptive ecosystem management. University of Chicago Press, Chicago Illinois, USA.

Norton, B. G., and D. Noonan. 2007. Ecology and valuation: big changes needed. Ecological Economics 63:664-675. http: //dx.doi.org/10.1016/j.ecolecon.2007.02.013

Norton, B. G., and A. Steinemann. 2001. Environmental values and adaptive management. Environmental Values 10 (4):473-506. http://dx.doi.org/10.3197/096327101129340921

Pellizzoni, L. 2001. The myth of the best argument: power, deliberation and reason. British Journal of Sociology 52:59-86. http://dx.doi.org/10.1080/00071310020023037

Proctor, W., and M. Drechsler. 2006. Deliberative multicriteria evaluation. Environment and Planning $C$ : Government and Policy 24:169-190. http://dx.doi.org/10.1068/ $\underline{\mathrm{c} 22 \mathrm{~s}}$

Raiffa, H. 1968. Decision analysis. Addison-Wesley, Reading, Massachusetts, USA.

Renn, O. 2006. Participatory processes for designing environmental policies. Land Use Policy 23:34-43. http://dx. doi.org/10.1016/j.landusepol.2004.08.005

Rodríguez, J. Paul, T. D. Beard, Jr., E. M. Bennett, G. S. Cumming, S. Cork, J. Agard, A. P. Dobson, and G. D. Peterson. 2006. Trade-offs across space, time, and ecosystem services. Ecology and Society 11(1): 28. [online] URL: http://www.eco logyandsociety.org/vol11/iss1/art28/

Shim, J. P., M. Warkentin, J. F. Courtney, D. J. Power, R. Sharda, and C. Carlsson. 2002. Past, present, and the future of decision support technology. Decision Support Systems 33:111-126. http://dx.doi.org/10.1016/S0167-9236(01)00139-7

Silver, J. 2008. Weighing in on scale: synthesizing disciplinary approaches to scale in the context of building interdisciplinary resource management. Society and Natural Resources 21:921-929. http://dx.doi.org/10.1080/08941920701617809 
Smith, N. 1992. Geography, difference and the politics of scale. Pages 57-79 in J. Doherty, E. Graham, and M. Malek, editors. Postmodernism and the social sciences. Macmillian, London, UK.

Smith, N. 1993. Homeless/global: scaling places. Pages 87-119 in J. Bird, editor. Mapping the futures: local cultures global change. Routledge, New York, New York, USA.

Smith, N. 1995. Remaking scale: competition and cooperation in prenational and postnational Europe. Pages 9-74 in $\mathrm{H}$. Eskelinen, and F. Snickars, editors. Competitive European peripheries. Springer Verlag, Berlin, Germany.

Songorwa, A. N. 1999. Community-based wildlife management (CWM) in Tanzania: are the communities interested? World Development 27(12):2061-2079. http://dx.d oi.org/10.1016/S0305-750X(99)00103-5

Stagl, S. 2006. Multicriteria evaluation and public participation: the case of UK energy policy. Land Use Policy 23:53-62. http://dx.doi.org/10.1016/j.landusepol.2004.08.007

Stirling, A. 2006. Analysis, participation and power: justification and closure in participatory multi-criteria analysis. Land Use Policy 23:95-107. http://dx.doi.org/10.1016/ j.landusepol.2004.08.010

Sunderland, T., C. Ehringhaus, and B. M. Campbell. 2008. Conservation and development in tropical forest landscapes: a time to face the trade-offs? Environmental Conservation 34 (4):276-279.

Swyngedouw, E. 1997a. Excluding the other: the production of scale and scaled politics. Pages 167-176 in R. Lee and J. Wills, editors. Geographies of economies. Arnold, London, UK.

Swyngedouw, E. 1997b. Neither global nor local: glocalization and the politics of scale. Pages 137-166 in K. Cox, editor. Spaces of globalization. Guilford Press, New York, New York, USA.

Swyngedouw, E. 1997c. Power, nature, and the city: the conquest of water and the political ecology or urbanization in Guayaquil, Ecuador: 1880-1990. Environment and Planning A 29 (2):311-332. http://dx.doi.org/10.1068/a290311

Swyngedouw, E. 2000. Authoritarian governance, power, and the politics of rescaling. Environment and Planning D: Society and Space 18(1):63-76. http://dx.doi.org/10.1068/d9s

van den Hove, S. 2006. Between consensus and compromise: acknowledging the negotiation dimension in participatory approaches. Land Use Policy 23:10-17. http://dx.doi.org/10.1 016/j.landusepol.2004.09.001
Vatn, A. 2002. Efficient or fair: ethical paradoxes in environmental policy. Pages 148-180 in J. Paavola and D. W. Bromley, editors. Economics, ethics, and environmental policy: contested choices. Blackwell, Oxford, UK.

Vatn, A., and D. W. Bromley. 1994. Choices without prices without apologies. Journal of Environmental Economics and Management 26:129-148. http://dx.doi.org/10.1006/jeem.199 $\underline{4.1008}$

Wells, M. P., and T. O. McShane. 2004. Integrating protected area management with local needs and aspirations. Ambio 33:513-519.

Wilkie, D., K. H. Redford, and T. O. McShane. 2010. Taking of rights for natural resource conservation: a discussion about compensation. Journal of Sustainable Forestry 29 (2-4):135-151. http://dx.doi.org/10.1080/10549810903543865

Wilson, M. A., and R. B. Howarth. 2002. Discourse-based valuation of ecosystem services: establishing fair outcomes through group deliberation. Ecological Economics 41:431-443. http://dx.doi.org/10.1016/S0921-8009(02)00092-7

Wittmer, H., F. Rauschmayer, and B. Klauer. 2006. How to select instruments for the resolution of environmental conflicts? Land Use Policy 23:1-9. http://dx.doi.org/10.1016/ j.landusepol.2004.09.003 